\title{
Translocation and Recovery Efforts for the Telkwa Caribou, Rangifer tarandus caribou, Herd in Westcentral British Columbia, 1997-2005
}

\author{
Astrid Vik Stronen ${ }^{1,2}$, Paul Paquet $^{1}$, Stephen Herrero ${ }^{1}$, SeÁn Sharpe ${ }^{3}$, and Nigel Waters ${ }^{4}$ \\ ${ }^{1}$ Faculty of Environmental Design, University of Calgary, 2500 University Drive NW, Calgary, Alberta T2N 1N4 Canada \\ ${ }^{2}$ Present Address: Department of Biology, University of New Brunswick, Fredericton, New Brunswick E3B 6C2 Canada; \\ Mailing Address: 6533 rue de Normanville, Montreal, Quebec H2S 2B8 Canada; e-mail: astrid.stronen@unb.ca \\ ${ }^{3}$ Ministry of Environment, \#325, 1011 Fourth Avenue, Prince George, British Columbia V2L 3H9 Canada \\ ${ }^{4}$ Department of Geography, George Mason University, 4400 University Drive MS 1E2, Fairfax, Virginia 22030 USA
}

Stronen, Astrid Vik, Paul Paquet, Stephen Herrero, Seán Sharpe, and Nigel Waters. 2007. Translocation and recovery efforts for the Telkwa Caribou, Rangifer tarandus caribou, herd in westcentral British Columbia, 1997-2005. Canadian FieldNaturalist 121(2): 155-163.

During 1997-1999, 32 Woodland Caribou (Rangifer tarandus caribou) were translocated from the Sustut Herd to the Telkwa Mountains in westcentral British Columbia to augment recovery of the Telkwa Caribou Herd. The animals were fitted with radiocollars and located during 1997-2000 to determine selection of habitat features and terrain variables. Six Caribou calves were also collared to determine causes and timing of calf mortality during summer 1999. Defining available habitat for newly translocated animals is often arbitrary and subjective, and we based the analyses on ranks for habitat use and availability as this is less sensitive to the inclusion or exclusion of a questionable resource. This method represents some loss of information but provides indications of the relative importance of various habitat types without classifying any as avoided. High elevation habitat $\left(>1700\right.$ masl) on moderate slopes $\left(16-45^{\circ}\right)$ received the highest ranks, as did "warm" $\left(136-315^{\circ}\right)$ aspects and forests $>250$ years old. Three calves died shortly after birth. One calf appeared to have been killed by predation, likely by a Golden Eagle (Aquila chrysaetos), and one calf was abandoned by the cow. Cause of death for the third calf is unknown. To assess habitat use associated with calving we compared summer locations with data obtained throughout the rest of 1999 for eight cows with calves and eight without calves. We found significant difference in use of elevation during calving time, when cows with calves remained at high elevations and barren cows generally descended to lower elevation habitat. Surveys conducted in 2005, five years after the completion of the initial study, produced a count of approximately 90 Caribou. This suggests that in the short term, the translocation was successful in re-establishing a self-sustaining Caribou population in the Telkwa Mountains.

Key Words: Woodland Caribou, Rangifer tarandus caribou, calf mortality, calving habitat, habitat selection, rank analysis, wildlife management, British Columbia.

Woodland Caribou (Rangifer tarandus caribou), populations have generally experienced decline and range reduction over the last century in British Columbia (Heard and Vagt 1998), across Canada (COSEWIC $\left.2000^{*}\right)$ and throughout the circumpolar region (Mallory and Hillis 1996). Causes of decline include a combination of habitat loss, habitat fragmentation, increased human access, hunting and predation (Bloomfield 1980; Edmonds and Bloomfield 1984; Heard and Vagt 1998), poaching (Edmonds 1988), and possible interactions between disturbance and predation (Mallory and Hillis 1996). Woodland Caribou in the Southern Mountain National Ecological Area of British Columbia (including the Telkwa Caribou Herd) were designated as threatened in 2000 (COSEWIC 2000*). Caribou were once widely distributed throughout the mountainous areas surrounding Telkwa and Smithers, British Columbia, and might have formed part of a larger herd whose range extended south into Tweedsmuir Provincial Park (TCHRP 1998*). Few data are available on the Telkwa Caribou Herd before 1997; however, surveys indicated fluctuations in herd size from less than 100 in 1949 to a high of 271 in 1965 . A hunting clo- sure was implemented for the herd in 1973 but only 68 animals were counted in 1984 (van Drimmelen 1986*) and monitoring flights in the 1990s resulted in counts of less than 20 Caribou (TCHRP 1998*). During 1997-1999, 32 Caribou were captured from the Sustut Herd about $150 \mathrm{~km}$ north of Smithers and translocated to the Telkwa Mountains to help the recovery of the Telkwa Caribou Herd.

Translocation is now a common tool in the recovery of populations at risk (Griffith et al. 1989) and the need for documenting habitat use and availability is critical in efforts to preserve endangered species and manage small populations (Manly et al. 1993). We studied habitat use and calf survival of the Telkwa Caribou Herd from 1997 to 2000 to determine preliminary habitat selection of translocated animals and assess timing and causes of calf mortality. With small populations following a translocation, there are usually limited data available to investigate habitat selection, and therefore little or no information for land managers. Although defining available habitat for newly translocated animals is often arbitrary and subjective, a preliminary evaluation of habitat selection can provide some infor- 
mation on priority areas for protection when assessing other land uses such as forestry and recreation. Translocation success can be evaluated in three phases: (1) initial occupation and reproduction in the new ecosystem; (2) presence of a short-term self-sustaining population, and (3) ultimate population recovery (Compton et al. 1995). We outline findings on habitat selection and calf mortality between 1997 and 2000 and report for phases 1 and 2 of the Telkwa Caribou Herd Recovery Project. We also discuss challenges involved in providing habitat management priorities based on preliminary data from a small reintroduced population.

\section{Study Area}

The study area comprises approximately $25000 \mathrm{~km}^{2}$ in westcentral British Columbia, with elevations ranging from 300-3000 meters above sea level (Figure 1). It is situated between 53.40 and 55.20 degrees of latitude north and 125.10 to 128.30 degrees of longitude west. Glaciers, rugged peaks, high alpine plateaus, and deep glaciated U-shaped valleys with extensive wetlands characterize the alpine areas. Major tree species in the study area include Subalpine Fir (Abies lasiocarpa), Engelmann Spruce (Picea engelmannii), and Hybrid White Spruce (Picea glauca $\times$ engelmannii). The climate has both coastal and inland influences, with cool summers and moderately cold winters. Precipitation averages $500 \mathrm{~mm}$ per year, of which about half falls as snow. The Telkwa Mountains have a population of approximately 250 Mountain Goats (Oreamnus americanus), and lower elevations have populations of Moose (Alces alces), Mule Deer (Odocoileus hemionus hemionus), and some Elk (Cervus elaphus). Large predators within the range of the Telkwa Caribou Herd include: Grizzly Bears (Ursus arctos), Black Bears (Ursus americanus), Wolverine (Gulo gulo), Wolves (Canis lupus), Coyotes (Canis latrans), and Golden Eagles (Aquila chryseatos). To account for the difficulty in defining available resources for the herd and thus delineating our study area, where most animals have had $<2$ years of experience, we selected an area of available habitat based on three factors: (1) locations of collared caribou 1997-1998 (G. Schultze, British Columbia Ministry of Environment, personal communication); (2) Traditional Ecological Knowledge of the Telkwa Caribou Herd (B. Holland, Wet'suwet'en First Nation, personal communication in Stronen 2000) and (3) availability of forest cover data from the British Columbia Ministry of Forests (Inventory Branch, Victoria, scale 1: 20 000).

\section{Methods}

We located radiocollared animals throughout the year from fixed wing aircraft (Cessna 206, 185, or 172) using standard telemetry equipment. Tracking intervals varied from every four days to every three weeks, depending on funding, season, and weather conditions.
We determined geographic location using yoke-mounted, handheld, or panel-mounted Global Positioning System (GPS) units and noted habitat characteristics, activity, group size, and presence of young. The accuracy of relocation data was tested and averaged \pm 300 meters. Most locations were determined during morning or mid-day. For the purpose and scale of this study, the data were assumed representative of Caribou habitat use for day and night. Six calves were captured shortly after birth and equipped with radiocollars during the summer of 1999. Caribou calves were captured as close to within 24 hours of birth as possible using a Bell 206 Jet Ranger and a Long Ranger helicopter and a capture crew of three people. Calves were sexed, weighed, and fitted with VHF radiocollars (Lotek Engineering, Newmarket, Ontario) with motion sensitive mortality sensors. We estimated age by assessing the presence/condition of the umbilical cord, condition of hooves and pelage, posture, and general appearance (Haugen and Speake 1958; Miller et al. 1988), and calculated weight by subtracting $0.6 \mathrm{~kg}$ for each day of estimated age (Adams et al. 1995). Handling time was approximately five minutes from capture to release. Calves were monitored daily, weather permitting, from date of capture until the end of August. During September and October, we monitored calves weekly and after October they were monitored as a part of regular telemetry flights for the herd. We investigated mortality signals via helicopter the day of discovery.

Data for elevation (meters above mean sea level), slope (\%), and aspect (in azimuth measured from north) were derived from a Digital Elevation Model using Arc/INFO v. 7 software. Tiles from the Digital Elevation Model were merged to form a seamless grid covering the study area. Floating point grids were generated for slope and aspect and we created a variable combining elevation and slope. Data on habitat type (leading tree species or non-productive timber area), crown closure $(\%)$, and tree age (using leading tree species) were derived from Forest Cover Inventory Polygons (British Columbia Ministry of Forests, Inventory Branch, Victoria, scale 1: 20 000). Values for terrain and habitat variables were summarized $\left(\mathrm{km}^{2}\right)$ for the entire study area to determine percent availability of the various classes of each variable. Habitat availability was analyzed by the British Columbia Ministry of Environment's regional GIS data analyst, who also produced cartographic output. We used data collected between November 1997 and April 2000 to analyse habitat use and determined terrain and forest cover values for all telemetry locations. To assess habitat selection, we followed sampling design 2 of Manly et al. (1993), where individual animals were identified and the use of resources was measured for each individual, but availability was measured at the population level.

To assess habitat use associated with calving, we used locations for eight cows with calves ( $n=123$ locations) and eight without calves ( $n=128$ locations) 


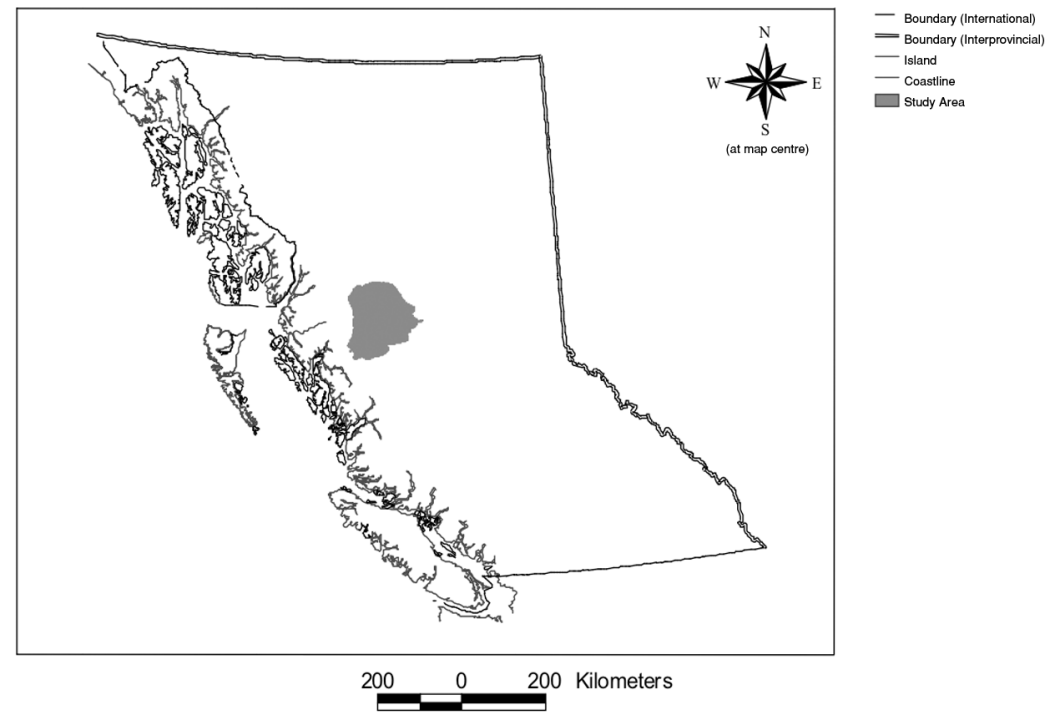

FIGURE 1. The study area in British Columbia, 1997 - 2000.

collected during the summer of 1999 . We compared summer data ( $n=150$ locations) with locations obtained during the rest of the year $(n=145$ locations) to account for differences not attributed to calving. Locations were divided into two groups:

(1) calving (25 May - 6 July)

(2) all-year (1 January - 24 May, and 7 July -31 December)

We analyzed habitat selection using Resource Selection for Windows (RSW), a 32-bit Windows program for analyzing preference (Leban 1999). Using Johnson's (1980) method, which orders all variable components by rank for usage and availability, we measured habitat preference for each animal as the difference between the rank of usage and the rank of availability. We averaged these differences across animals to obtain a mean value for each habitat component and then compared the values to determine a ranking from least preferred habitat component to most preferred. We tested for habitat selection using alpha $=0.05$. We compared habitat use of reproductive cows and cows without calves using analysis of variance (repeated measures, alpha $=0.05$ ) within each group and within each season using SPSS 10.0 (SPSS Inc. 1999). The herd consisted primarily of translocated Caribou during the study and we considered the radio-collared animals to be a random sample of the Telkwa Herd.

\section{Results}

High elevation habitat on moderate slopes $(>1700$ meters above sea level, $16-45 \%$ ) received the highest ranks (Table 1). Caribou also made extensive use of the steep rugged mountains in the Telkwa range $(>1700 \mathrm{~m},>45 \%)$. Aspects $136-315^{\circ}$ received the highest rank (Table 2). The rank values for aspect appear to contradict the information on use versus availability. However, data on use report only overall percentage of use, and taking behavior of individual animals into account; the $136-315^{\circ}$ aspects receive the highest rank. Less than $1 / 3$ of locations (405 of 1424) were in forested habitats (Table 3), and of these locations, forests $>250$ years old received the highest rank.

For analysis within groups, we found a significant difference in mean elevation between calving time and the rest of the year for cows without calves, but not for cows with calves. For analysis within season, we found a significant difference in mean elevation for calving time but not for the rest of the year. Although sample sizes were smaller for calving time, both groups had a narrower range in elevation during calving and individual differences in elevation use were also higher during calving than the remainder of the year (Figures $2-5$ ). Figure boxes represent the interquartile range containing $50 \%$ of the values, with a line showing the median value. Error bars represent the highest and lowest values, excluding outliers (extreme values). Most cows gave birth in alpine locations, in exposed areas free of snow. Of the 16 cows sampled, only cow \#151 made extensive use of elevations below 1400 meters throughout the year (Figure 4).

Calving time for Telkwa Caribou ranged from 26 May until 10 June, and six Caribou calves were collared between 3 June and 10 June 1999. Five were males born to transplanted Caribou cows and one was a female calf born to the only resident collared cow. Average birth weight was $8.4 \mathrm{~kg}$ (range $6.9-9.4 \mathrm{~kg}$ ). Three of the six calves died shortly after birth. One calf likely died from abandonment, whereas cause of 
TABLE 1. Use, availability and rank of classes for elevation and slope. Telkwa Mountains, British Columbia, Canada 1997-2000. $\mathrm{N}=1424$

\begin{tabular}{|c|c|c|c|c|c|c|}
\hline Elevation (m) & Slope (\%) & Class & Locations & $\%$ use & $\%$ available & Rank \\
\hline$<1100$ & $0-15$ & 1 & 116 & 8.15 & 38.43 & 9 \\
\hline$<1100$ & $16-45$ & 2 & 38 & 2.67 & 20.75 & 8 \\
\hline$<1100$ & $>45$ & 3 & 4 & 0.28 & 6.40 & 7 \\
\hline $1100-1700$ & $0-15$ & 4 & 166 & 11.66 & 17.98 & 6 \\
\hline $1100-1700$ & $16-45$ & 5 & 303 & 21.28 & 9.71 & 4 \\
\hline $1100-1700$ & $>45$ & 6 & 168 & 11.80 & 3.00 & 5 \\
\hline$>1700$ & $0-15$ & 7 & 144 & 10.11 & 2.18 & 3 \\
\hline$>1700$ & $16-45$ & 8 & 313 & 21.98 & 1.18 & 1 \\
\hline$>1700$ & $>45$ & 9 & 172 & 12.08 & 0.36 & 2 \\
\hline
\end{tabular}

TABLE 2. Use, availability and rank of classes for aspect. Telkwa Mountains, British Columbia, Canada 1997-2000. N = $1416^{\mathrm{a}}$

\begin{tabular}{lccccc}
\hline \hline Aspect (azimuth) & Class & Locations & $\%$ use & $\%$ available & Rank \\
\hline $136-315$ & 1 & 627 & 44.03 & 47.24 & 1 \\
$316-135$ & 2 & 789 & 55.41 & 48.23 & 2 \\
\hline \hline
\end{tabular}

a Areas of zero aspect (usually where relocation error positioned animals in water) are excluded.

TABLE 3. Use, availability and rank of classes for forest age. Telkwa Mountains, British Columbia, Canada 1997-2000. N = 405

\begin{tabular}{|c|c|c|c|c|c|}
\hline Forest age (years) & Class & Locations & $\%$ use & $\%$ available & Rank \\
\hline$\overline{1-40}$ & 1 & 18 & 1.26 & 8.47 & 4 \\
\hline $41-100$ & 2 & 84 & 5.90 & 17.82 & 3 \\
\hline $101-140$ & 3 & 105 & 7.37 & 14.85 & 2 \\
\hline $141-250$ & 4 & 161 & 11.31 & 24.60 & 5 \\
\hline$>250$ & 5 & 37 & 2.53 & 7.08 & 1 \\
\hline
\end{tabular}

${ }^{\mathrm{b}}$ Including only locations below tree line $(1700 \mathrm{~m})$.

death for the second calf appeared to be avian predation, most likely Golden Eagle. Cause of death for the third calf was unknown. The calf had remains of what appeared to be milk curds in the stomach and small amounts of vegetation. However, membranes inside the hide appeared dry and indicated dehydration. No signs of predation or scavenging were evident. We found adult tracks, likely made by the mother, circling the carcass. During the first year after the transplant (1998), we observed five calves in the herd. The following year, we saw one yearling in the herd, as well as 12 new calves and one cow with an extended udder, indicating she recently had given birth and lost her calf. We observed eight calves during the 1999 October calf count. Recent surveys of the herd found 16 cows with calves in October 2003 and 23 the following year. In October 2005 ten cows with calves were counted. However, the decrease in cow/calf numbers from 2004 to 2005 may reflect fewer functioning radio collars in the herd during 2005, thus increasing the probability that some Caribou groups went undetected (G. Schultze, personal communication).

\section{Discussion}

The Telkwa Caribou Herd appears to select high elevation habitat with moderate slopes, which corresponds with earlier observations (van Drimmelen 1986*; Bill Holland, personal communication in Stronen 2000). The herd uses gentle to moderate slopes throughout much of the year, which is common for Woodland Caribou (Edmonds and Bloomfield 1984; Seip 1990*; Terry et al. 1996; Wood and Terry 1999). However, use of steep slopes is also reported (Hatler 1987*; Terry et al. 1996). Woodland Caribou have been found using southern/warm aspects (Edmonds and Bloomfield 1984; Warren et al. 1996), northern/cool aspects (Warren et al. 1996) or to show no apparent selection (Seip 1990*). Use also varies between years and seasons (Terry et al. 1996; Wood and Terry 1999). When in forested habitat the Telkwa Caribou Herd appears to select old forests, which corresponds with other studies (Cichowski 1993; Terry et al. 1996; Wood and Terry 1999; Apps and Kinley 2000*). Woodland Caribou in British Columbia have been classified into two ecotypes (Stevenson and Hatler 1985). The north- 


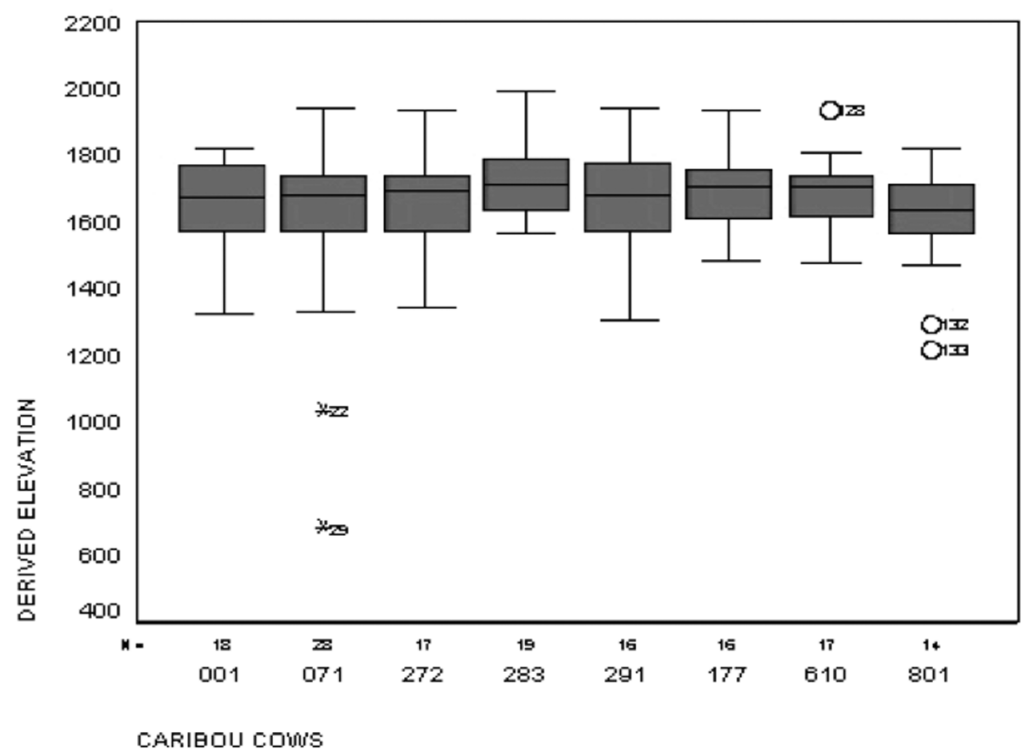

FIGURE 2. Barren cows' use of elevation all-year, 1999. Telkwa Mountains, British Columbia.

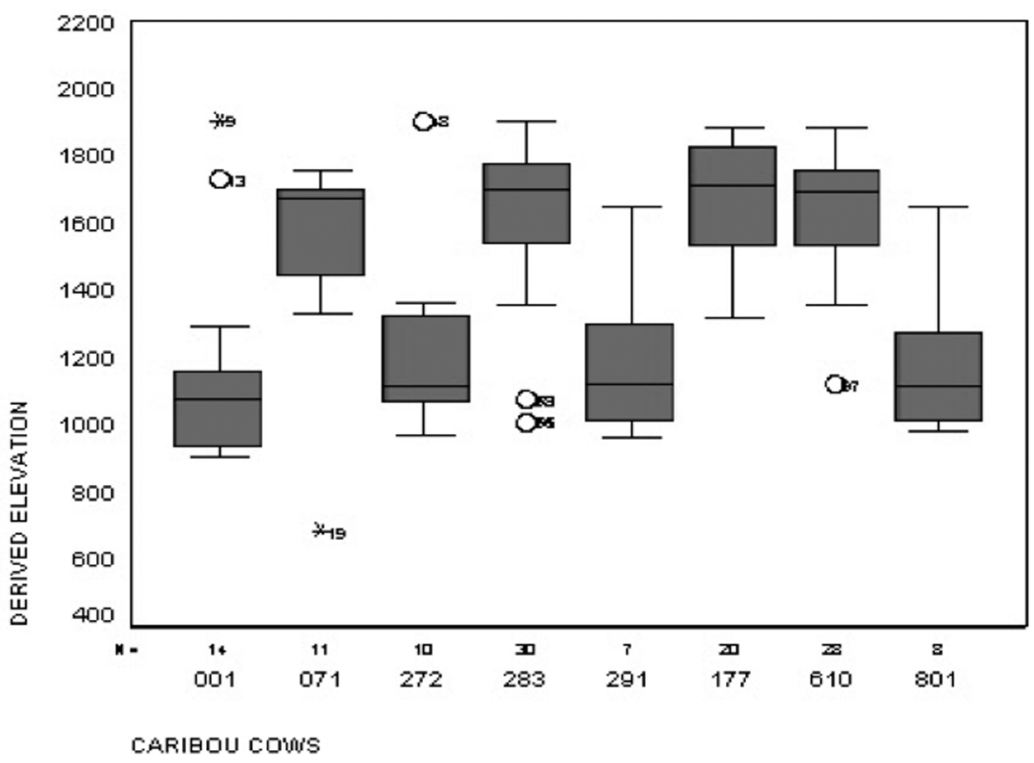

Figure 3. Barren cows' use of elevation at calving time, 1999. Telkwa Mountains, British Columbia.

ern ecotype (including the Telkwa Caribou Herd) depends primarily on terrestrial lichens during winter and the mountain ecotype depends more on arboreal lichens. Arboreal lichens are most abundant in old forest (Apps and Kinley 2000*), often on trees $>120$ years old (Stevenson and Hatler 1985; Wood and Terry 1999). We found the Telkwa Caribou Herd in forested habitat only one-third of the time. However, divisions between arboreal- and terrestrial lichen-dependent groups are not absolute. The temporal impacts of icing, deep snow, and other environmental conditions may at times prevent Caribou from obtaining terrestrial lichens, making areas of arboreal lichens provisionally more important (van Drimmelen 1986*; Edmonds 1988; Cichowski 1993). Forests 141-250 years old received the highest use but the lowest rank. This is the most abundant forest age class (Table 3). Whereas the small number of Caribou during this study did not use this age class 
in proportion to availability, the low rank does not equal avoidance or lack of importance. Future monitoring could also help clarify whether certain areas within this forest age class are locally important.

The difference in elevation use between barren and reproductive cows during calving season might be due to reproductive status. There are, however, wide differences within each group. As four of eight barren cows remained at high elevations (which presumably meant forgoing nutritional opportunities, at least in spring/early summer), this could be an antipredator strategy employed regardless of reproductive status. Based on this study, possible antipredator tactics for protecting a calf can not be distinguished from those that cows seem to use for their own protection. Edmonds and Smith (1991) reported that cow/calf pairs localised movement to relatively small geographic areas in early June (1-15) and did not increase the size of their ranges until after July. The Telkwa Caribou displayed similar behaviour, as cow/calf pairs in the Telkwa Herd remained relatively stationary until the middle of July. Subsequently, some pairs made long distance movements (one pair moved $50 \mathrm{~km}$ over a few days). The calving time for Telkwa Caribou corresponded to that reported by Edmonds (1988) for westcentral Alberta. As only one birth from a resident Caribou was recorded (10 June), it was not possible to examine any differences between transplant and resident animals.

Some cows in the Telkwa Caribou Herd appeared more sensitive to fixed-wing aircraft during the first couple of weeks post-calving than during the rest of the year, but we noted a wide range in behaviour. Cichowski (1993) reported that most adult females were found alone on ridge tops during calving. Two Telkwa cows calved on the top of a rocky ridge and were joined by two other cows with calves in the middle of June. The ridge had few access points but biophysical information suggests low potential for lichen production. All four calves were found alive in October. The use of ridges may be a trade-off between predator avoidance and the availability of abundant high protein food (Bergerud and Miller 1984). Cichowski (1993) found that most calving sites were within $10 \mathrm{~km}$ of previous calving sites and Seip (1990*) reported many Caribou use the same calving locations each year. We could not analyse fidelity to calving areas within the Telkwa Herd and it would take several years before this could be assessed. Caribou calving areas could change from year to year as an antipredator strategy (Bergerud and Miller 1984), and Valkenburg et al. (1988) warned against making management decisions based on Caribou calving areas located during narrow time intervals. However, previously known calving areas identified by the Traditional Ecological Knowledge of the Wet'suwet'en First Nation (B. Holland, in Stronen 2000) should be considered when making management decisions, as this information is based on years of observation and would indicate fidelity to specific calving sites.

Small sample size precluded analysis of calf mortality for the Telkwa herd but suggested that avian predation was a factor. Recruitment data from November 1998 to April 2000 seemed to indicate that low production of calves was a factor of equal or higher importance than the loss of calves. If the low recruitment of calves was due to calf predation, a higher frequency of Caribou cows with extended udders but without calves would be expected. Females without calves commonly shed their antlers in March and April and exhibit fresh antler growth during the calving period, whereas pregnant females shed their antlers near calving in May and June (Bergerud 1980). During our surveys at calving time, many cows exhibited fresh antler growth, indicating that they were not expecting a calf that year. The Caribou transplanted from the Sustut Caribou Herd would be expected to show pregnancy rates comparable to those of other populations when they arrived, and reported pregnancy rates usually range from $80 \%$ to $90 \%$ (Bergerud 1980; Seip 1990*; Edmonds and Smith 1991). It is possible that stress related to capture, immobilization, and transplant may have caused abortions or fetal absorptions, or that a large number of the cows were by chance not pregnant. In addition, there may not have been enough bulls to achieve normal pregnancy rates for the Telkwa herd during the first years. At least one resident mature bull was present in the herd during 1998 but due to difficulties associated with movement and collaring of adult bulls only younger males were translocated to the Telkwa Mountains.

Human activities such as recreation and resource extraction may also influence Caribou habitat use. Van Drimmelen (1986*) expressed trepidation over snowmobiling on the winter ranges of the Telkwa Herd and this has been a concern for over 25 years (Bustard $\left.1977^{*}\right)$. The presence of dogs may also cause Caribou to avoid otherwise useful habitat. This is particularly important during calving time, when cows may be extra sensitive to disturbance (Bergerud and Miller 1984). Need for information related to species translocations and/or small remnant populations will increase in the future. Where habitat availability is poorly estimated it may be particularly important not to label habitats and resources, which may be important in the long term, as avoided. We chose Johnson's (1980) method because it is relatively insensitive to decisions on what constitutes available habitat for the Telkwa Caribou Herd. If habitat components are used in proportion to availability, the rank ordering of use and availability will be the same. However, the converse is not necessarily true; the use and availability proportions could be different across habitat components, while still having the same rank, thus resulting in high Type 2 errors (where a difference in proportional selection is not detected) (Alldredge and Ratti 1986, 


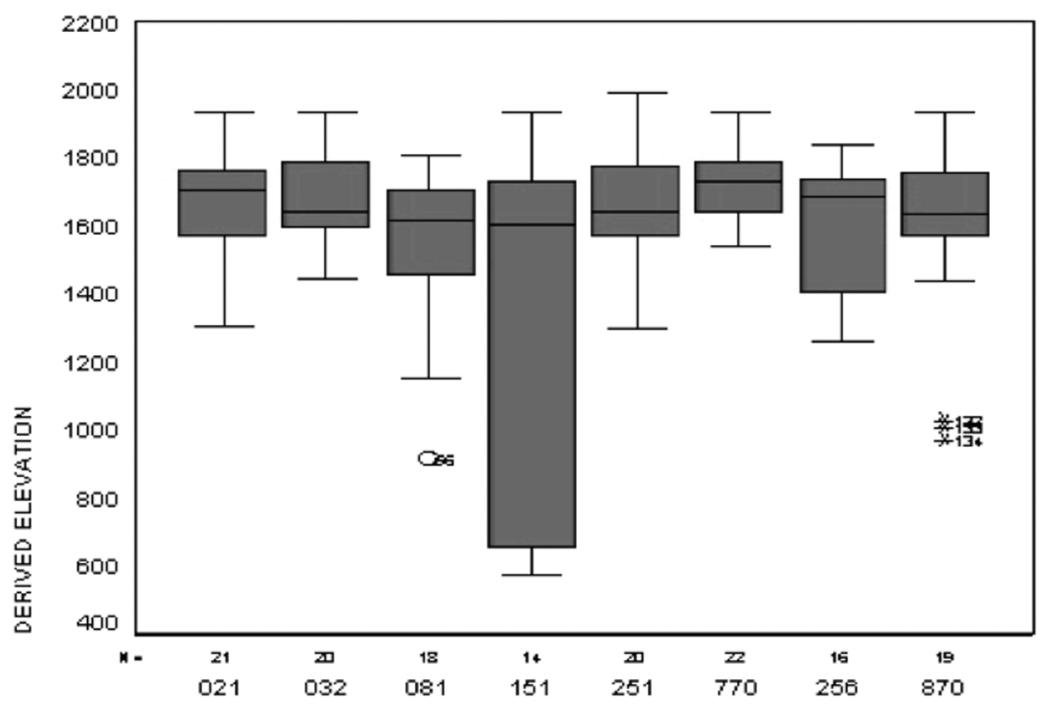

CARIBOU COW'S

FIGURE 4. Reproductive cows' use of elevation all-year, 1999. Telkwa Mountains, British Columbia.

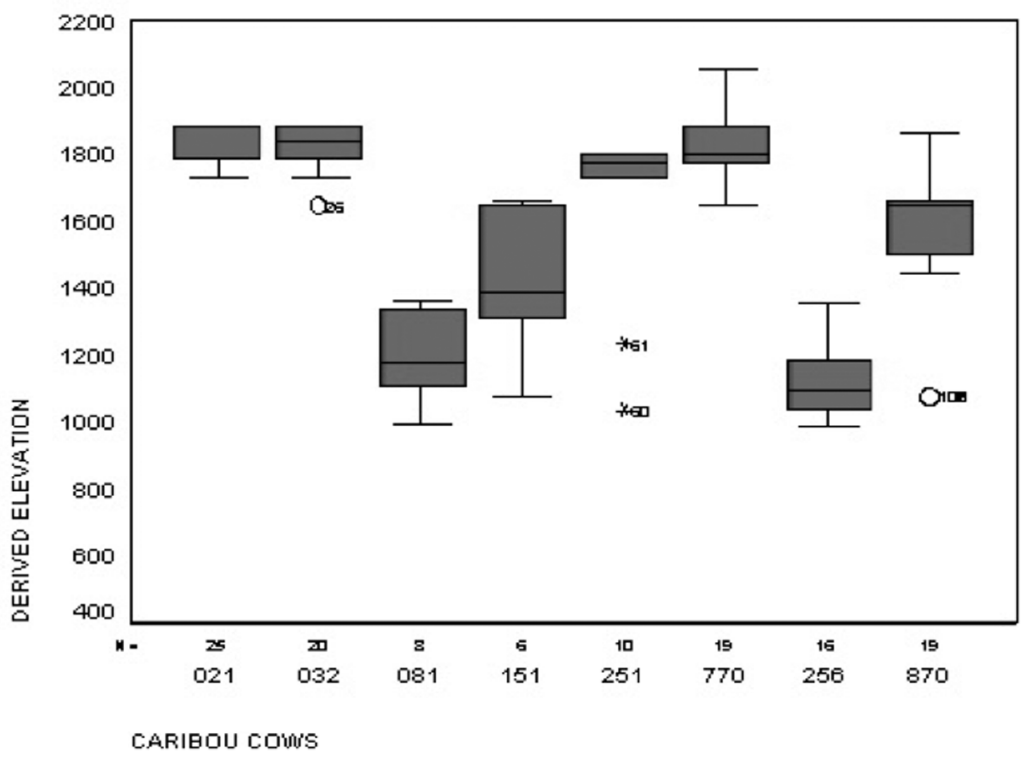

FIGURE 5. Reproductive cows' use of elevation during calving time, 1999. Telkwa Mountains, British Columbia.

1992). A bias may also occur against small habitat patches when the size of error area for locations [here $\pm 300 \mathrm{~m}$ ] is independent of habitat patch size (Rettie and McLoughlin 1999). Many wetlands in our study area were too small to be captured in Forest Cover data and Houwers (1996*) reported that distribution of arboreal lichens in the Telkwa Mountains was patchy. These two habitat units, too small to be noted by our analysis, may be vital for long-term survival of the Telkwa Caribou Herd. The size of habitat required by Caribou to avoid predation may be significantly greater than the amounts required to obtain sufficient forage (Stevenson et al. 1994*; Seip and Cichowski 1996), and requirements for predation avoidance could be 10 times larger (Bergerud 1980). It is theorized that the Telkwa Mountains could support approximately 
300 caribou (van Drimmelen 1986*). Given sufficient habitat and calf survival the herd could recover to historic numbers. At present, the translocation appears to have been successful in establishing a self-sustaining Caribou herd in the Telkwa Mountains.

\section{Acknowledgments}

The Habitat Conservation Trust Fund, Forest Renewal BC, the British Columbia Ministry of Environment, and a Graduate Research Scholarship from the Faculty of Environmental Design, University of Calgary, provided funding for this study. Staff at the British Columbia Ministry of Environment in Smithers assisted with fieldwork, and G. Schultze provided survey data from 2000 to 2005 . We thank J. Warren and other staff at the GIS-section for help with all GIS-related work. Northern Lights Air piloted fixedwing telemetry flights, and Canadian Helicopters piloted flights to capture caribou calves and investigate mortalities. An anonymous reviewer provided helpful comments on the manuscript.

\section{Documents Cited (marked * in text)}

Apps, C., and T. Kinley. 2000. Multi-scale habitat associations of Mountain Caribou in the Southern Purcell Mountains, British Columbia. East Kimberley Environmental Society, Kimberley British Columbia and Crestbrook Forest Industries Ltd., Cranbrook, British Columbia.

Bustard, D. 1977. Caribou observations - Hunter's Basin Camel Humps Area. Fish \& Wildlife Branch memorandum, Ministry of Environment, Lands and Parks, 14 March, 1977.

COSEWIC. (Committee on the Status of Endangered Wildlife In Canada) 2000. Updated Status Report on the Woodland Caribou (caribou des bois) Rangifer tarandus dawsoni and Rangifer tarandus caribou in Canada. Available at http://www.sararegistry.gc.ca/virtual_sara/files/cose wic/sr_woodland_caribou_e.pdf

Hatler, D. F. 1987. Perspectives on inventories of caribou in British Columbia. Spatsizi Association for Biological Research Report (4). Wildlife Report (R-14) July 1987.

Houwers, C. 1996. Lichen Abundance Inventory of the Telkwa Range. British Columbia Ministry of Environment, Lands and Parks, Smithers.

Seip, D. R. 1990. Ecology of woodland caribou in Wells Gray Provincial Park. Wildlife Bulletin B-68, March 1990. Ministry of Environment, Wildlife Branch, Victoria, British Columbia and Ministry of Parks, Kamloops, British Columbia.

Stevenson, S. K., H. M. Armleder, M. J. Jull, D. G. King, E. L. Terry, G. S. Watts, B. N. McLellan and K. N. Child. 1994. Mountain Caribou in Managed Forests: Preliminary Recommendations for Managers. Ministry of Forests, Research Branch, Victoria, British Columbia.

TCHRP (Telkwa Caribou Herd Recovery Plan). 1998. Telkwa Caribou Herd Recovery Team, British Columbia Ministry of Environment, Lands and Parks, Skeena Region, British Columbia, Canada

van Drimmelen, B. 1986. Telkwa Mountains Caribou Telemetry Project, Progress Report \# 2. Ministry of Environment, Smithers, British Columbia

\section{Literature Cited}

Adams, L. G., F. J. Singer, and B. W. Dale. 1995. Caribou calf mortality in Denali National Park, Alaska Journal of Wildlife Management 59: 584-594.

Alldredge, J. R., and J. T. Ratti. 1986. Comparison of some statistical techniques for analysis of resource selection. Journal of Wildlife Management 50: 157-165.

Alldredge, J. R., and J. T. Ratti. 1992. Further comparison of some statistical techniques for analysis of resource selection. Journal of Wildlife Management 56: 1-9.

Bergerud, A. T. 1980. A review of the population dynamics of caribou and wild reindeer in North America. Pages 556-581 in Proceedings of the $2^{\text {nd }}$ International Reindeer/ Caribou Symposium, Røros, Norway. Edited by E. Reimers, E. Gaare, and S. Skjenneberg. Direktoratet for vilt og ferskvannsfisk, Trondheim.

Bergerud, A. T., and D. R. Miller. 1984. Antipredator tactics of calving caribou: dispersion in mountains. Canadian Journal of Zoology 62: 1566-1575.

Bloomfield, M. 1980. The impact of development, settlement and associated activities on mountain caribou in Central British Columbia, Canada. Pages 705-715 in Proceedings of the $2^{\text {nd }}$ International Reindeer/Caribou Symposium, Røros, Norway. Edited by E. Reimers, E. Gaare, and S. Skjenneberg. Direktoratet for vilt og ferskvannsfisk, Trondheim.

Cichowski, D. B. 1993. Seasonal movements, habitat use and winter feeding ecology of woodland caribou in west-central British Columbia. Ministry of Forests, Research Branch, British Columbia. Land Management Report (79).

Compton, B. B., P. Zager, and G. Servheen. 1995. Survival and mortality of translocated woodland caribou. Wildlife Society Bulletin 23: 490-496.

Edmonds, E. J. 1988. Population status, distribution and movements of woodland caribou in west central Alberta. Canadian Journal of Zoology 66: 817-826.

Edmonds, E. J., and M. I. Bloomfield. 1984. A study of woodland caribou (Rangifer tarandus caribou) in west central Alberta, 1979-1983. Alberta Energy and Natural Resources, Fish and Wildlife Division.

Edmonds, E. J., and K. G. Smith. 1991. Mountain caribou calf production and survival, and calving and summer habitat use in west-central Alberta. Alberta Forestry, Lands and Wildlife, Fish and Wildlife Division. Wildlife Research Series (4).

Griffith, B., J. M. Scott, J. W. Carpenter, and C. Reed. 1989. Translocation as a conservation tool: status and strategy. Science 245: 477-480.

Haugen, A. O., and D. W. Speake. 1958. Determining age of young white tailed deer. Journal of Wildlife Management 22: 319-321.

Heard, D. C., and K. L. Vagt. 1998. Caribou in British Columbia: A 1996 status report. Rangifer Special Issue 10: 117-123.

Johnson, D. J. 1980. The comparison of usage and availability measurements for evaluating resource preference. Ecology 61: 65-71.

Leban, F. 1999. Resource Selection Analysis Software for Windows 95/NT Version 1.00 Beta 8.1 (8. Jan. 1999).

Mallory, F. F., and T. L. Hillis. 1996. Demographic characteristics of circumpolar caribou populations: ecotypes, ecological constraints, releases, and population dynamics. Rangifer Special Issue 10: 49-60.

Manly, B., L. McDonald and D. Thomas. 1993. Resource Selection by Animals. Statistical Design and Analysis for Field Studies. Chapman \& Hall, London. 
Miller, F. L., E. Broughton, and A. Gunn. 1988. Mortality of migratory barren-ground caribou on the calving grounds of the Beverly herd, Northwest Territories, 1981-83. Canadian Wildlife Service, Occasional Paper (66).

Rettie, W. J., and P. D. McLoughlin. 1999. Overcoming radiotelemetry bias in habitat-selection studies. Canadian Journal of Zoology 77: 1175 - 1184.

Seip, D. R., and D. B. Cichowski. 1996. Population ecology of Caribou in British Columbia. Rangifer Special Issue 9: 73-80.

SPSS, Inc. 1999. SPSS for Windows, version 10.0.

Stevenson, S. K., and D. F. Hatler. 1985. Woodland caribou and their habitat in southern and central British Columbia. Volume 1. British Columbia Ministry of Forests, Victoria, British Columbia Report (23).

Stronen, A. V. 2000. Habitat Selection and Calf Survival in the Telkwa Caribou Herd, British Columbia 1997-2000. M.Sc. thesis, Faculty of Environmental Design, University of Calgary, Alberta, Canada

Terry, E., B. McLellan, G. Watts, and J. Flaa. 1996. Early Winter Habitat Use by Mountain Caribou in the North
Cariboo and Columbia Mountains, British Columbia Rangifer, Special Issue 9: 133-140.

Valkenburg, P., J. L. Davis, and D. J. Reed. 1988. Distribution of radio-collared caribou from the Delta and Yanert herds during calving. Pages 14-25 in Proceedings of the $3^{\text {rd }}$ North American Caribou Workshop, Cheena Hot Springs, Alaska 1987. Edited by R. D. Cameron, and J. L. Davis. Alaska Department of Fish and Game. Wildlife Technical. Bulletin (8).

Warren, C. D., J. M. Peek, G. L. Servheen and P. Zagers. 1996. Habitat use and movements of two ecotypes of translocated Caribou in Idaho and British Columbia. Conservation Biology 10: 547-553.

Wood, M. D., and E. L. Terry. 1999 Seasonal movements and habitat selection by woodland caribou in the Omineca Mountains, North-Central British Columbia. Phase 1: The Chase and Wolverine Herds (1991-1994). Peace/Williston Fish and Wildlife Compensation Program Report (201).

Received 17 May 2006

Accepted 10 March 2008 